\title{
Coconut Shell Activated Carbon as an Alternative Renewable Energy
}

\author{
Erlinda Sulistyani ${ }^{\mathrm{a} *}$, Daniel Boi Tamado ${ }^{\mathrm{a}}$, Futri Wulandari ${ }^{\mathrm{a}}$, Esmar Budi $^{\mathrm{a}}$ \\ ${ }^{a}$ Department of Physics, Faculty of Mathematics and Science, State University of Jakarta, Jln. Pemuda No.10, Jakarta Timur 13220, Indonesia
}

\begin{abstract}
Research coconut shell activated carbon as an alternative renewable energy has been done. Coconut shell activated carbon is processed into fuel that can replace coal. Coconut shell densely textured, hard, and old became a mainstay to be used as activated carbon. The process of forming into a coconut shell coconut shell activated carbon made by drying, pyrolysis, and carbonization. After it was examined DSC and SEM, so the coconut shell activated carbon obtained temperature of $500{ }^{\circ} \mathrm{C}$ is activated carbon which can produce the greatest heat and durable because of the many elements contained carbon and many pores are formed.
\end{abstract}

Keywords: activated carbon; alternative renewable energy; coconut shell.

\section{Introduction}

Limitations of fuel oil in Indonesia is expected in the next few years will be completed stock. According to data from the Agency for the Assessment and Application of Technology ( BPPT ), supplies of fossil energy resources in Indonesia is expected to only last a few more years. Gas supplies in Indonesia last about 30 years, coal fuel to last about 50 years, and fuel to last about 11 years. To overcome the energy crisis that happened made fossil fuel consumption restriction program and the insistence on the provision of energy reserves in the form of alternative energy. One alternative energy biomass. Biomass energy is renewable energy derived from waste organic matter and very diverse species as crop farming, agriculture, and forest [1].

Indonesian coconut in large enough to make Indonesia as one of the largest oil producing country in the world. Coconut which has the Latin name Cocos nucifera has many benefits both from the leaves, fruits, stems [2]. Coconut fruits to eat as well as raw material for coconut oil, but coconut shell waste generated is increasing. Coconut shell is one of the waste oil processing is quite large, reaching $60 \%$ of oil production [3].In order not to reduce the aesthetic value of the environment, waste can be processed coconut shell as a biomass feedstock [4]. Coconut shell activated carbon is processed into fuel that can replace coal. The process of making activated carbon is relatively easy, inexpensive, and has a high use value. In terms of quality, including a coconut shell activated carbon materials that provide good enough quality activated carbon. Coconut shell densely textured, hard, and old became a mainstay to be used as activated carbon [5]. The quality of coconut shell and the combustion process will greatly affect the out come of the yield of activated carbon produced. The amount of waste coconut shell and fuel crisis prompted researchers undertake manufacture of coconut shell activated carbon in the form of pellets as a fuel replacement for coal energy.

\footnotetext{
* Corresponding author. Tel.: +62 8788890700.

E-mail address: erlinda.sulistyani@yahoo.com
} 


\section{Material and methods}

\subsection{Material preparation}

Coconut shell derived from Yogyakarta. The process of preparation is done by cleaning coconut shell using aquades that aims to reduce the impurities that are still tied to coconut shell [3].

\subsection{The process of manufacture of coconut shell activated carbon}

The process of coconut shell formation to coconut shell activated carbon made with some level. First, drying coconut shell for two day to reduce moisture in the shell. Second pyrolysis process coconut shells in a kiln furnace, pyrolysis process takes approximately 6 hours and temperature range between (70 to 150$)^{\circ} \mathrm{C}$ [6]. From the pyrolysis process to produce charcoal. Coal crushed twice to get powdered charcoal is fine. Then mixing charcoal powder, starch, and water with the composition comparison of charcoal powder : starch is $10: 2$, while the water composition is regulated as needed. Material printed using the hydrolic compactor, pressure of 2 ton and molt, diameter of $2.5 \mathrm{~cm}$. Sample printout suppressed in the room for one night. Once the sample is dry do carbonization process using the furnace for 30 minute with the temperature variations as follows $200{ }^{\circ} \mathrm{C}, 300{ }^{\circ} \mathrm{C}, 400{ }^{\circ} \mathrm{C}$, and $500{ }^{\circ} \mathrm{C}$

\subsection{Analysis of glass transition temperature and microstructure coconut shell actived carbon}

Charcoal glass transition temperature can be determined by using DSC (Different Scanning Calorimetry). While the pore and particle shape as well as the elements contained in coconut shell activated carbon can be determined by using SEM (Scanning Electron Microscopy).

\section{Results and discussion}

Coconut shell activated carbon can be the one of the alternative fuel because its high absorption and good thermal properties are reviewed [4]. Selection of coconut shell as main material for activated carbon base on good thermal properties can be viewed from the heat of combustion, glass temperature ( $\mathrm{Tg}$ ) and melting temperature (Tm). Tests of performed base on the thermal properties of the sample using DSC (Different Scanning Calorimetry) with $11.9 \mathrm{mg}$ of fine charcoal powder and shades of $100 \%$ nitrogen gas with a flow rate of $40 \mathrm{~mL} / \mathrm{min}$, the samples were tested using aluminum crucible by heating to a temperature of $600{ }^{\circ} \mathrm{C}$, after which the sample was cooled slowly returned to ambient conditions $27^{\circ} \mathrm{C}$. The test results showed that the transition of glass temperature $(\mathrm{Tg})$ is at a point $339^{\circ} \mathrm{C}$ with a melting temperature $(\mathrm{Tm})$ in the range point of $508.5^{\circ} \mathrm{C}$ to $678^{\circ} \mathrm{C}$. If the temperature higher than $339^{\circ} \mathrm{C}$, the fine charcoal powder will be plastic (plasticity), whereas when its temperature lower than $339^{\circ} \mathrm{C}$, the fine charcoal powder are fragile (brittleness). Samples of fine charcoal powder becomes difficult to elastic because of the high glass transition temperature of the resulting powder does not melt quickly, so it can generate a large combustion heating value. 


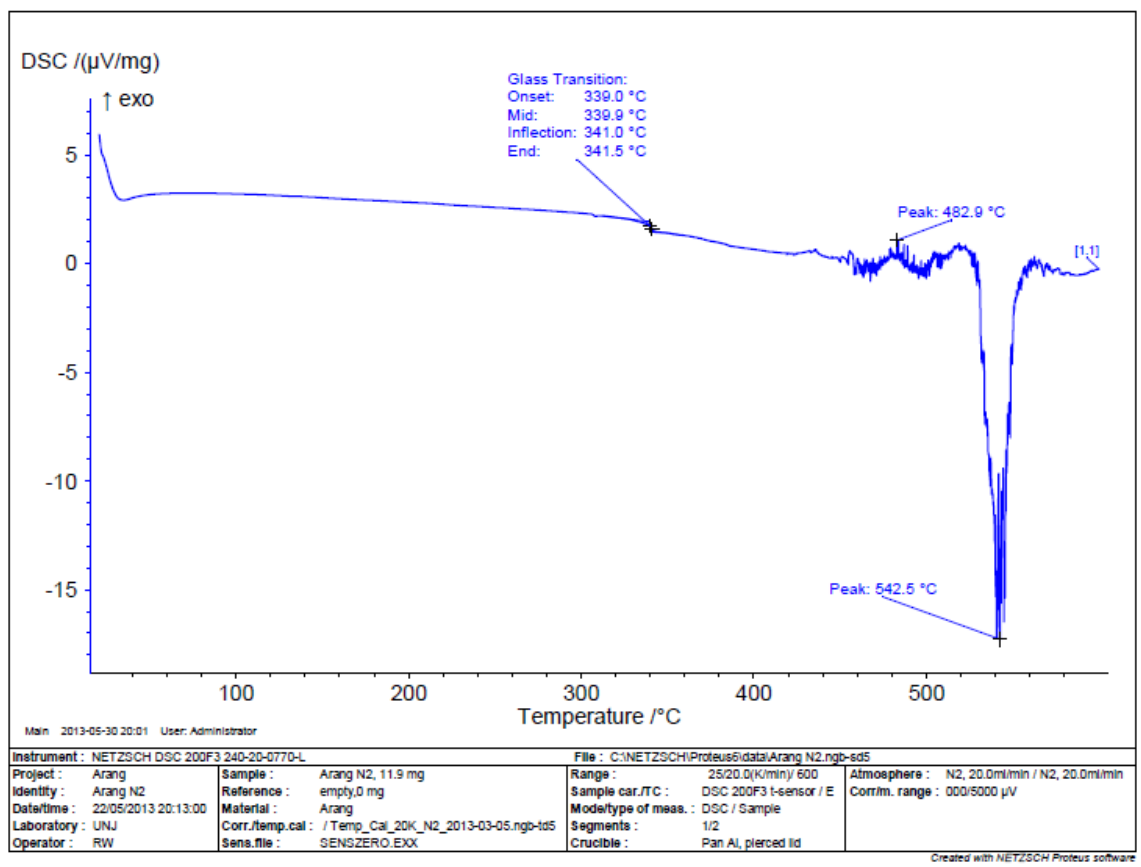

Fig. 1. Results of DSC charcoal powder.

Manufacture of coconut shell activated carbon in the pellets form with variations of carbonization temperature experienced shrinkage of the mass. The mass data were obtained:

Table 1. Mass of activated carbon samples.

\begin{tabular}{ccc}
\hline Temperature of carbonitation & Mass before carbonitation & Mass after carbonitation \\
\hline $200{ }^{\circ} \mathrm{C}$ & 6.753 & 5.870 \\
$300^{\circ} \mathrm{C}$ & 6.753 & 5.010 \\
$400^{\circ} \mathrm{C}$ & 6.753 & 4.734 \\
$500{ }^{\circ} \mathrm{C}$ & 6.753 & 4.201 \\
\hline
\end{tabular}


Shrinkage mass from the calculation has been done and graph obtained as follows:

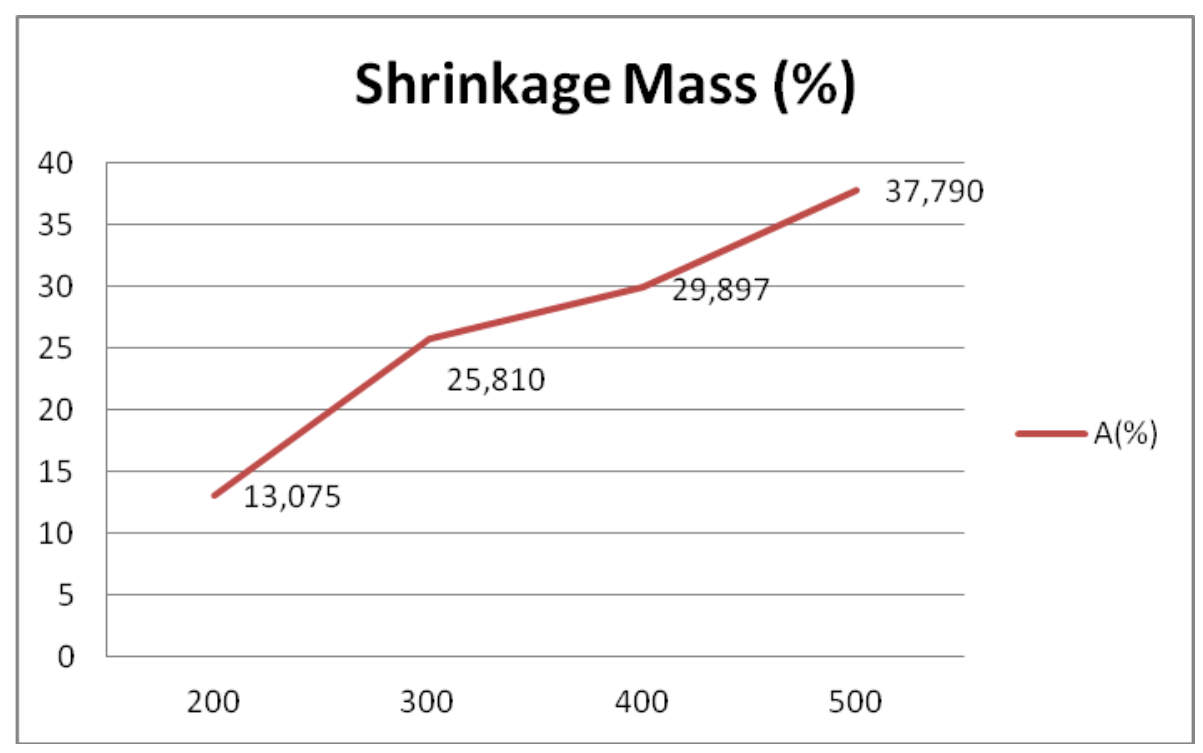

Fig. 2. Shrinkage mass coconut shell activated carbon.

Shrinkage mass occurred in the largest temperature of $500{ }^{\circ} \mathrm{C}$.

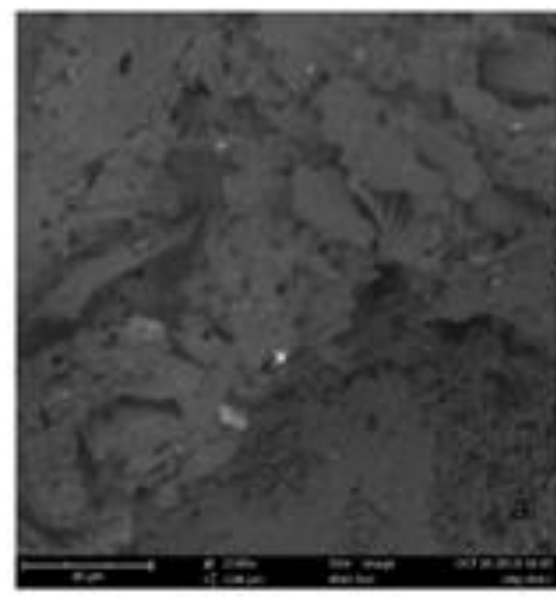

(a)

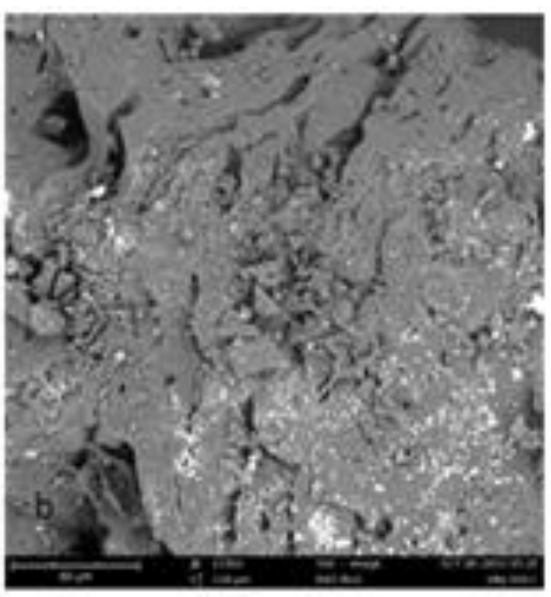

(b)

Fig. 3. SEM images of activated carbon at temperature of $300{ }^{\circ} \mathrm{C}$ (a) and $500{ }^{\circ} \mathrm{C}$ (b).

The test of two samples performed using SEM at temperature of $300{ }^{\circ} \mathrm{C}$ and $500{ }^{\circ} \mathrm{C}$, at the temperature of $500{ }^{\circ} \mathrm{C}$ is produce pore number and surface area larger than activated carbon at temperature of $300{ }^{\circ} \mathrm{C}$. Pore form more clear at each temperature increase [5].

If carbonization temperature increase, the result of concentration of volatile matter (methane, hydrocarbons, hydrogen, nitrogen) and impurities decrease. That process cause carbon becomes the dominant element. Both of 
activated carbon samples in Figure 4 and Figure 5 contain $\mathrm{O}, \mathrm{C}, \mathrm{K}, \mathrm{Al}$ elements. From these images, there is an increase of carbon elements contained in both samples. Activated carbon at temperature of $500{ }^{\circ} \mathrm{C}$ has content of $31.7 \%$ carbon, more than at temperature of $300{ }^{\circ} \mathrm{C}$ which only has content of $24.8 \%$.

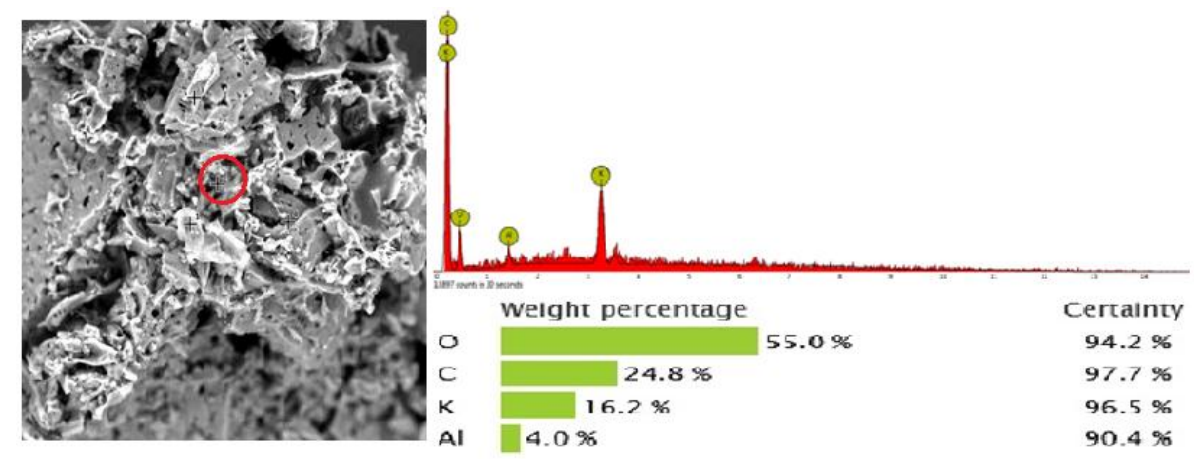

Fig. 4. SEM EDS image of activated carbon at temperature of $300^{\circ} \mathrm{C}$.

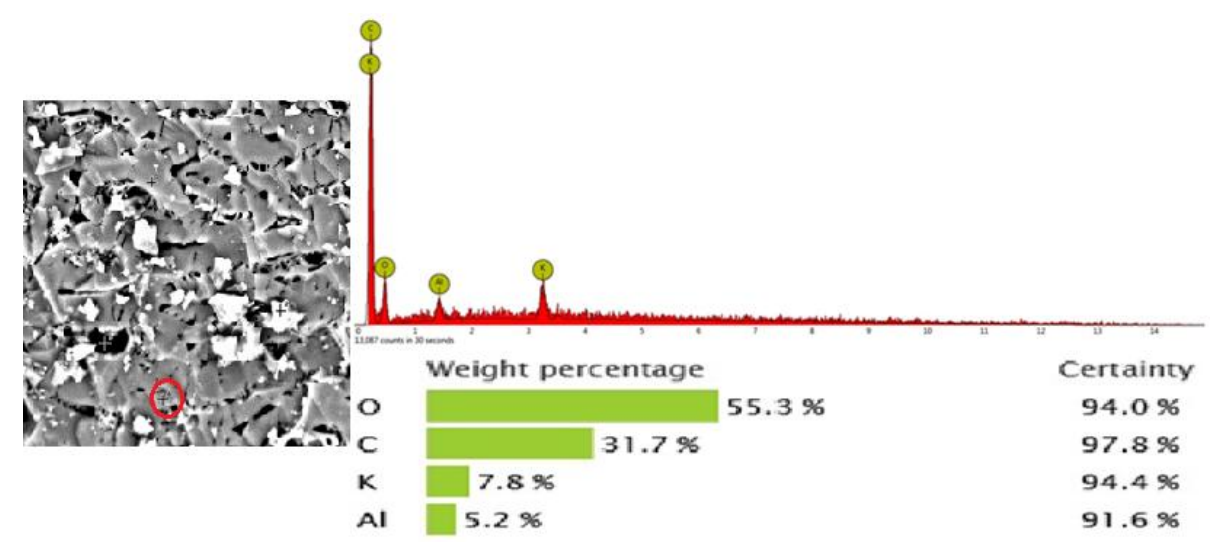

Fig. 5. SEM EDS image of activated carbon at temperature of $500^{\circ} \mathrm{C}$.

Reduced volatile matter and substance impurities in the sample at each temperature increase causes shrinkage of the mass thus leaving empty spaces (pores) in the sample. Evenly distributed pores made the greater surface area resulting in touch calorific value increases [8].

\section{Conclusion}

If the temperature of carbonization increase, mass reduction pores more numerous and pore surface area, volatile substances and impurities matter recedes until the element carbon contained a dominant element. The thermal properties of coconut shell activated carbon is closely linked to the amount of pore and particle size. Coconut shell activated carbon at temperatur of $500^{\circ} \mathrm{C}$ can produce the heat and long lasting because many carbon is contained and the number of pores is formed.

\section{Acknowledgements}

The authors are thankful to Esmar Budi and M. Fajrin Sofyan for support of facilities in this research. 


\section{References}

[1] Mozammel, H.M., Masahiro, O., Bhattacharya SC. Activated Charcoal from Coconut Shell using ZnCl2 Activation. Biomass and Bioenergy, Vol. 22 (2002), pp. 397-400.

[2] Meilita Tryana Sembiring, Tuti Sarma Sinaga. Arang Aktif. Sumatera Utara:USU (2003).

[3] Elly Kurniati. Pemanfaatan Cangkang Kelapa Sawit sebagai Arang Aktif. Jawa Timur:Jurnal Penelitian Ilmu Teknik, Vol.8 (2008), No.2, Hal. 96-10.

[4] M. Syamsiro dan Harwin Saptoadi. Pembakaran Briket Biomassa Cangkang Kakao Pengaruh Temperatur Udara Preheat, Seminar Nasional Teknologi (2007)

[5] Esmar Budi, Tinjauan Proses Pembentukan dan Penggunaan Arang Tempurung Kelapa sebagai Bahan Bakar. Jurnal Penelitian Sains FMIPA Unsri. Vol. 14 (2011), No.4, pp. 14406-25

[6] Siti Jamilatun, Martomo Setyawan. Pembuatan Arang Aktif dari Tempurung Kelapa dan Aplikasinya untuk Penjernihan Asap Cair. Yogyakarta:Spektrum Industri. Vol. 12 (2014), No. 1, ISSN 1963-6590

[7] Elly Kurniati. Pemanfaatan Cangkang Kelapa Sawit sebagai Arang Aktif. Jawa Timur:Jurnal Penelitian Ilmu Teknik, Vol.8 (2008), No.2, Hal. 96-10

[8] Satriyani Siahaan, Melvha Hutapea, Rosdanelli Hasibuan. Penentuan Kondisi Optimum Suhu dan Waktu Karbonisasi pada Pembuatan Arang dari Sekam Padi. Sumatera Utara: Jurnal Teknik Kimia USU, Vol. 2 (2013), No. 1 